\title{
Phylogenetic Relationships of the Korean Trigonotis Steven (Boraginaceae) Based on Chloroplast DNA (cpDNA) and Nuclear Ribosomal Markers (nrDNA) Region
}

\author{
Ngoc Ai Trinh, Hien Thi Thanh Nguyen and Seon Joo Park* \\ Department of Life Science, Yeungnam University, Gyeongsan 712-749, Korea
}

\begin{abstract}
We performed phylogenetic analyses of a total of 21 acessions covering 5 species in the Korean Trigonotis and one outgroup species using nuclear ribosomal ITS and chloroplast $r b c L$, matK, $n d h F$ sequences. Outgroup were chosen from the closely related genus Lithospermum zollingeri. Both parsimony and Bayesian Inference methods were used to reconstruct the evolutionary history of the group. The evidence collected indicated that phylogenetic relationships among Korean Trigonotis species are unresolved based on nuclear marker (ITS), as the same as based on separated chloroplast sequences. While the phylogenetic relationships of Korean Trigonotis species almost clearly were resolved in combined chloroplast sequences. Thus, the members of Trigonotis coreana can be distinguished to the members of Trigonotis peduncularis in combined cpDNA sequences and Trigonotis nakaii was treated as a synonymed to Trigonotis radicans var. sericea. In addition, the MP and BI analysis showed Trigonotis icumae as sister of the remained Korean Trigonotis species based on combined molecular markers (BI: $\mathrm{PP}=1)$.
\end{abstract}

Key words - nrDNA, cpDNA and Triogonotis

\section{Introduction}

The genus Trigonotis, the small one in family Boraginaceae, consists of about 58 species, distributed in Asia, E. Europe (Wang, 1982; Zhu et al., 1995), China (39 species), with 33 endemic species. Members of the Trigonotis genus is perennial, biennial herbs, or rarely annual plants and grown in grassy places and in lowland areas. It has single or several stems and cespitose, erect to diffuse, hispid or pilose, rarely glabrous. Calyx is 5-lobed or 5-parted. Corolla is blue or white with center yellow; throat appendages 4. Cymes are solitary or dichotomously branched, ebracteate or lower pedicels bracteate, rarely all bracteates (flowers extra axillary).

Morphological characteristics of Trigonotis genus are arguments and confusing. Maximovicz (1872) collected Omphalodes sericea that was transferred to Trigonotis by Johnston (1937). One year later, Ohwi (1953) put a taxon into synonymy of what he considered to be Trigonotis radicans together with Omphalodes sericea Maximovicz and Omphalodes

${ }^{*}$ Corresponding author. E-mail : sjpark01@ynu.ac.kr aquatic is an additional synonym of Trigonotis radicans. According to Popov (1953), he identified Maximowicz' and other author plants under the name of Trigomotis radicans as Trigonotis coreana Nakai (1917). Furthermore, Lee (1996) mentioned that Trigonotis icumae (Maxim.) is synonym to Omphalodes icumae Maxim. Trigonotis peduncularis (Treviranus) Bentham is synonym Eritrichium japonicum Miq., Eritrichium pedunculare (Trevir.) A.DC., Myosotis chinensis. A.DC., Myosotis peduncularis Trevir., and Trigonotis radicans var. sericea is synonym to Omphalodes sericea Maxim., $T$. coreana Nakai, T. sericea (Maxim.) I.M. Johnston, T. nakaii Hara. Morphological classification is not only time-consuming but also it may not distinctly distinguished closely related species. In the recent years, molecular studies that have provided insights about genes based on rRNA gene sequences are more popular. The existence of unique substitutions plays a key role in distinguishing among closely related species. One of the useful tools for phylogenetic inference at the generic and infrageneric level in plants is the Internal Transcribed Spacer (ITS) region of the 18S-5.8S-26S nuclear ribosomal DNA (nrDNA) that has used well as a phylogenetic 
marker in most groups of flowering plants (Baldwin, 1992). However, there are several problems in the concerted evolution, the presence of pseudogenes as well as the existence of paralogs and orthologs (Bailey et al., 2003; Feline and Rosello', 2007; Mayol and Rossello', 2001; Soltis et al., 2008). The chloroplast genome has been proved as a useful tool for species identification as well as in ecological and evolutionary studies (Newmaster et al., 2006; Kress and Erickson, 2007; Lahaye et al., 2008). The slowly evolving gene $r b c \mathrm{~L}$, indicating that can be used at the generic level. Thus, in the interordinal or intrafamilial level, the utility of $r b c L$ is limited. However, it sometimes has been used for phylogenetic analyses at species levels in angiosperms (Xiang et al., 1993; Azuma et al., 2000; Jovanovic' and Cvetkovic', 2010). The matK and $n d h F$ gene are applied in phylogenetic reconstructions at high taxonomic levels, such as Order or Family, however, sometimes also at low taxonomic categories, such as Genus or Species (Wolfe, 1991; Olmstead et al., 1998 Hilu et al., 2003; Muller et al., 2006; Chase et al., 2007;). In the present paper, we focus on sequence data from the nuclear internal transcribed spacer regions (ITS) and chloroplast DNA (cpDNA) to find out genetic diversity and the phylogenetic relationships among Korean Trigonotis genus.

\section{Materials and Methods}

\section{Taxon sampling}

The taxon sample comprised 20 individuals covering 5 species and scored for analyses. Those include five individuals of Trigonotis nakaii, five individuals of Trigonotis radicans var. sericea, two individuals of Trigonotis icumae, three individuals of Trigonotis coreana and five individuals of Trigonotis peduncularis, all from the Herbarium. We used

Table 1. Taxa included in the present study, with voucher information on country of location, herbarium. GN (Gyeongsangnamdo),CB (Chungcheongbuk-do), JN (Jeollanam-do), GW (Gangwon-do), GB (Gyeongsangbuk-do), JB (Jeollabuk-do)

\begin{tabular}{|c|c|c|}
\hline Accession & Locality & $\begin{array}{l}\text { Specimen } \\
\text { Vouchers }\end{array}$ \\
\hline Trigonotis nakaii Hara (T01) & GN, Miryang-si, Pyochungsa & YNUH0406 \\
\hline Trigonotis nakaii Hara (T02) & JB, Gochang, Mt. Seonunsan & YNUH0006 \\
\hline Trigonotis nakaii Hara (T03) & GN, san-cheong-gun, Sam-jang-myeon, Mt. Jirisan & KHB1067120 \\
\hline Trigonotis nakaii Hara (T04) & JB, Gokseong-gun, Mt. Tong-myeong-san & KHB1102046 \\
\hline Trigonotis nakaii Hara (T05) & CB, Boeun-gun, Naesongni-myeon, Mansu-ri & KWNU57636 \\
\hline Trigonotis radicans var. sericea (Maxim.) Hara (T06) & JB, Boseong-gun, Mundeok-myeon, Juksan-ri, Daewonsa & KHB1073595 \\
\hline Trigonotis radicans var. sericea (Maxim.) Hara (T07) & JB, Gochang-gun, Mt. Seonunsan & KHB1107968 \\
\hline Trigonotis radicans var. sericea (Maxim.) Hara (T08) & JN, Boseong-gun, Bongnae-myeon, Mt. Cheonbongsan & KHB1098995 \\
\hline Trigonotis radicans var. sericea (Maxim.) Hara (T09) & JN, Boseong-gun, Mundeok-myeon, Juksan-ri, Daewonsa jubyeon & KHB1088453 \\
\hline Trigonotis radicans var. sericea (Maxim.) Hara (T10) & JN, Hwasun-gun, Nam-myeon, Unsan-ri, Mt. Malbongsan & KHB1088533 \\
\hline Trigonotis icumae (Maxim.) Makino (T11) & GB, Sangui-ri, Budong-myeon, Mt. Juwangsan & KHB1187802 \\
\hline Trigonotis icumae (Maxim.) Makino (T12) & GW, Dutasan (Mt.), Hajang-myeon, Samcheok-si & KHB1170955 \\
\hline Trigonotis coreana Nakai (T13) & GB, Daegu, Mt. apsan & YNUH0044 \\
\hline Trigonotis coreana Nakai (T14) & GB, Chilgok-gun Yeonhodong & YNUH08054 \\
\hline Trigonotis coreana Nakai (T15) & JN, Yeongdae bongwan dwitpyeon & YUNH1690027 \\
\hline Trigonotis peduncularis (Trevir.) Benth. ex Heml (T16) & GB, Cheongdo-gun Unmun-myeon, Mt. Unmunsa & YNUH0505 \\
\hline Trigonotis peduncularis ((Trevir.) Benth. ex Heml (T17) & GN, Namhae-gun Mijo-myeon Nogumaeul Haeanga & KHB1 164795 \\
\hline Trigonotis peduncularis (Trevir.) Benth. ex Heml (T18) & JN, Hampyeong-gun Haebo-myeon, Mt. Moaksan & KHB1 158275 \\
\hline Trigonotis peduncularis (Trevir.) Benth. ex Heml (T19) & GW, Chuncheon-si, Mt. Bonguisan & KWNU66396 \\
\hline Trigonotis peduncularis (Trevir.) Benth. ex Heml (T20) & Jeju-si, Yongnunioreum & KWNU74892 \\
\hline Lithospermum zollingeri A. DC. & GB, Daegu, Dalseonggun, Mt. hwaryongsan & YNUH00022 \\
\hline
\end{tabular}


Phylogenetic Relationships of the Korean Trigonotis Steven (Boraginaceae) Based on Chloroplast DNA (cpDNA) and Nuclear Ribosomal Markers (nrDNA) Region

Lithospermum zollingeri as an outgroup because of morphological similar characters and Trigonotis 's sister group (Table 1).

\section{DNA extraction, amplification and sequencing}

Total genomic DNA from dried leaf materials were collected from Herbarium and extracted by a modified CTAB protocol from Doyle and Doyle (1987). For this study, three chloroplast markers, such as $r b c \mathrm{~L}, \mathrm{O} 1 \mathrm{~F}$ and O1R (Les, 1994); matK, T590F and T1320R (Sang et al., 1997); ndhF included two primer pairs, 599F-1354R and 1318F-2110R (Sweeney and Price. 2000; Olmstead and Sweere, 1994) were conducted to evaluate the suitability of various markers for the present study and the internal transcribed spacers from the nuclear ribosomal DNA (ITS) (White et al., 1990) was used. The $n d h \mathrm{~F}$ gene was amplified in two overlapping fragments, while the others were amplified in one fragment, using the primers listed in the Table 2. Polymerase chain reaction (PCR) conditions for the amplification were as follows : $96^{\circ} \mathrm{C}$ for $1 \mathrm{~min}$ followed by 30 to 35 cycles of $95^{\circ} \mathrm{C}$ for $30 \mathrm{sec}, 50$ to $56^{\circ} \mathrm{C}$ for $30 \mathrm{sec}, 72^{\circ} \mathrm{C}$ for $1 \mathrm{~min}$ and a final extension of $72^{\circ} \mathrm{C}$ for $10 \mathrm{~min}$. The amount of product was quantified using agarose gel electrophoresis with a low mass DNA ladder using the QIAquick PCR purification Kit (Qiagen, Crawley), following the manufactures' protocol. After that, the PCR production was sent to the Solgent Company for sequencing.

\section{Phylogenetic analyses}

All regions were sequenced using both forward and reverse primers. Sequences were assembled in Sequencher 3.0 (Gene Codes, Ann Arbor, Michigan, USA) and aligned manually in MacClade v. 408 (Maddison and Maddison, 2005). A consensus sequence was generated when the sequences from the forward and reverse primer were aligned for each taxon. Indels were coded separately using the simple indel coding method (Simmons and Ochoterena, 2000). Regions with ambiguous alignments were excluded. The phylogenetic analyses were set up in two steps. In the first step, the sequences of the nrDNA and cpDNA were analysed separately. In the second step, a combined analysis of the nrDNA and cpDNA was carried out. The combined matrix is used for incongruence between nuclear and chloroplast markers. Molecular trees based on the unweighted pair group method with arithmetic mean (UPGMA), Neighbor Joining (NJ), Maximum Parsimony (MP) were performed in PAUP* version 4.0b10 (Swofford, 2002). Heuristic bootstrap analysis was performed with 1,000 bootstrap replicates, 100 random addition cycles per bootstrap replicate, TBR swapping and equal weights. The resolution of species was characterized by calculating the percentage of species recovered as monophyletic based on phylogenetic trees. Clades with bootstrap percentages of 50\%-74\% are described as weakly supported; $75 \%-89 \%$ as moderately supported; $90 \%-100 \%$ as strongly supported.

Table 2. Oligonucleotide primers used in the PCR amplification and sequencing of DNA marker loci

\begin{tabular}{|c|c|c|c|}
\hline Region & Primer sequemce from the $5^{\prime}-3$ ' & $\begin{array}{l}\text { Pre-melt/ Amplication/ Final extention/ Number } \\
\text { of cycles in the amplication }\end{array}$ & Reference \\
\hline ITS4 & TCCTCCGCTTATTGATATGC & \multirow{2}{*}{$\begin{array}{l}95^{\circ} \mathrm{C}(3 \mathrm{~min}) / 95^{\circ} \mathrm{C}(30 \mathrm{sec})+56^{\circ} \mathrm{C}(30 \mathrm{sec})+ \\
72^{\circ} \mathrm{C}(1 \mathrm{~min}) / 72^{\circ} \mathrm{C}(10 \mathrm{~min}) / 35\end{array}$} & \multirow{2}{*}{ White et al.1990 } \\
\hline ITS5 & GGAAGTAAAAGTCGTAACAAGG & & \\
\hline$r b c L$ & & \multirow{3}{*}{$\begin{array}{l}95^{\circ} \mathrm{C}(4 \mathrm{~min}) / 95^{\circ} \mathrm{C}(30 \mathrm{sec})+52-54^{\circ} \mathrm{C}(1 \mathrm{~min})+ \\
72^{\circ} \mathrm{C}(1 \mathrm{~min}) / 72^{\circ} \mathrm{C}(7 \mathrm{~min}) / 35-40\end{array}$} & \multirow{3}{*}{$\begin{array}{l}\text { Les }(1994) \\
\text { Tsukaya et al. } \\
(1997)\end{array}$} \\
\hline $\mathrm{O} 1 \mathrm{~F}$ & ATGTCACCACAAACAGAGACTAAAGC & & \\
\hline O1R & CTTCTGCTACAAATAAGAATCGATCTCTCCA & & \\
\hline $\operatorname{mat} \mathrm{K}$ & & \multirow{3}{*}{$\begin{array}{l}96^{\circ} \mathrm{C}(2 \mathrm{~min}) / 95^{\circ} \mathrm{C}(1 \mathrm{~min})+52^{\circ} \mathrm{C}(1 \mathrm{~min})+72{ }^{\circ} \mathrm{C} \\
(1 \mathrm{~min}) / 72^{\circ} \mathrm{C}(10 \mathrm{~min}) / 35\end{array}$} & \multirow{3}{*}{ Sang et al (1997) } \\
\hline $\mathrm{T} 590 \mathrm{~F}$ & AAGACCCCTCTTCTTGCAT & & \\
\hline T1320R & GATCCGCTATAATAATGAGA & & \\
\hline$n d h F$ & & \multirow{5}{*}{$\begin{array}{l}95^{\circ} \mathrm{C}(3 \mathrm{~min}) / 94^{\circ} \mathrm{C}(20 \mathrm{sec})+45^{\circ} \mathrm{C}(40 \mathrm{sec})+ \\
72^{\circ} \mathrm{C}(1 \mathrm{~min}) / 72^{\circ} \mathrm{C}(5 \mathrm{~min}) / 35\end{array}$} & \multirow{5}{*}{$\begin{array}{l}\text { Sweeney \& Price } \\
(2000) \\
\text { Olmstead \& } \\
\text { Sweerel (1994) }\end{array}$} \\
\hline $599 \mathrm{~F}$ & TAGGTCTTTATTGGATAAC & & \\
\hline $1354 \mathrm{R}$ & AAATGTCCTTCAAAAGTAAG & & \\
\hline $1318 \mathrm{~F}$ & GGATTAAC(CT)GCATTTTATATGTTTCG & & \\
\hline $2110 \mathrm{R}$ & СССССТА(СТ)ATATTTGATACCTTCTCC & & \\
\hline
\end{tabular}


Bayesian analyses were reconstructed with MrBayes 3.1.1 (Ronquist and Huelsenbeck, 2003). Searches were conducted using two independent runs, each performed with four simultaneous chains. In addition, the statistical test was used: the Incongruence length difference (ILD) test as a suitable first step in detecting incongruences (Cunningham. 1997; Hipp et al., 2004). The ILD test, called the partition homogeneity test (PHT) in PAUL ${ }^{*}$ version 4.0b10 (Swofford, 2003), computed 1000 replicates with MAX-TREES option set to 100 and was executed on the combined dataset, excluding coded indels, and after removing constant characters from the matrix. The PHT was conducted on the combined chloroplast dataset as well, to test two chloroplast markers against each other.

\section{Results}

\section{Sequence characteristics of the Korean Trigonotis species}

Sequences for Trigonotis and outgroup taxa were generated for all plastid and nuclear markers selected. The data sets showed different levels of sequence variation and contained various indels (Table 3 ). The aligned sequences derived from all the cpDNA regions and the ITS revealed differences in the sequences length of 20 accessions covering 5 species in Korean Trigonotis and L. zollingeri as an outgroup. The tree length of ITS region is the highest, comparing to other primers. The $r b c \mathrm{~L}$ data sets included 83 steps, with a CI of 0.976 ; a RI of $0.818 ; 0.62 \%$ of all characters were potentially parsimony-informative; 562 characters were constant and 76 characters were parsimony-uninformative. The MP analysis of the mat $\mathrm{K}$ regions comprised 30 steps, 670 of constant and 29 of parsimony-uninformative. Although the data sets of mat K marker were the lowest parsimony-informative ( $0.14 \%)$, the consistency and retention index were the highest ratio $(\mathrm{CI}=1$ and $\mathrm{RI}=1)$, similarity with $n d h \mathrm{~F}$ regions. The $n d h \mathrm{~F}$ sequences resulted in an aligned matrix of 1525 characters. The MP analysis for this marker was 77 of tree length, 1450 characters were constant and 22 characters parsimonyuninformative (Table 3). The phylogenetic relationships are unresolved based on the NJ, MP and BI analysis of each chloroplast marker. The topology of $r b c \mathrm{~L}$ provided better resolution at lower levels, with Trigonotis species. The topology of matK data sets was similar to the topology of $n d h \mathrm{~F}$ sequences, showing the unresolved relationships within clades. Overall, matK presented the lowest percentage of informative sites, comparing to $n d h \mathrm{~F}(0.14 \%$ for $m a t \mathrm{~K}$ and $3.48 \%$ for $n d h \mathrm{~F}$, respectively).

\section{Phylogenetic analysis of the combined plastid sequences}

The aligned chloroplast sequences were 2867 characters; 2,697 characters were constant; 164 characters are parsimonyuninformative while only 6 characters were parsimonyinformative. Maximum parsimony analysis resulted in 176 steps, with CI of 0.972 and RI of 0.839 , resulting in less homoplasy than ITS data. When analyzing the chloroplast regions, they share the same history due to their linkage, no

Table 3. Sequence characteristics and tree statistic of the cpDNA and ITS regions from the maximum-parsimony (MP) analysis

\begin{tabular}{|c|c|c|c|c|c|c|}
\hline \multirow{2}{*}{ Characteristics } & \multicolumn{3}{|c|}{ cpDNA } & \multirow{2}{*}{$\begin{array}{c}\text { nrDNA } \\
\text { ITS }\end{array}$} & \multirow{2}{*}{$\begin{array}{l}\text { Combined } \\
\text { cpDNA }\end{array}$} & \multirow{2}{*}{$\begin{array}{c}\text { Combined } \\
\text { cpDNA and ITS }\end{array}$} \\
\hline & $r b c \mathrm{~L}$ & matK & $n d h \mathrm{~F}$ & & & \\
\hline LAS (bp) & $627-645$ & $698-718$ & 1525 & $685-719$ & 2867 & 3526 \\
\hline TL & 83 & 30 & 77 & 187 & 176 & 1623 \\
\hline PICs* & $4(0.62 \%)$ & $1(0.14 \%)$ & $53(3.48 \%)$ & $86(13.11 \%)$ & $6(0.21 \%)$ & $87(2.47 \%)$ \\
\hline CI & 0.976 & 1.000 & 1.000 & 0.930 & 0.972 & 0.900 \\
\hline RI & 0.818 & 1.000 & 1.000 & 0.957 & 0.839 & 0.945 \\
\hline $\mathrm{RC}$ & 0.798 & 1.000 & 1.000 & 0.890 & 0.815 & 0.935 \\
\hline Constant & 562 & 670 & 1450 & 498 & 2697 & 1939 \\
\hline Parsimony-uninformative & 76 & 29 & 22 & 72 & 164 & 1500 \\
\hline
\end{tabular}

LAS, length of aligned sequences; TL, tree length; PICs, parsimony-informative characters (number and percent); CI, consistency index, RI, retention index; HI, homoplasy index; RC, rescaling consistency index. 
suprising in finding of the same topologies. We cannot see error or misalignment when checking the alignment of the coding spacers of taxa. The coding region has fewer changes and the signal appears to be overhelmed in the combined analyses. In the BI analysis, the AICc selected the GTR $+\Gamma+\mathrm{I}$ substitution model. In the combined plastid sequences, the NJ, MP and BI analysis were shown the same topology trees. The results provided Trigonotis radicans var. sericeae species were related to Trigonotis nakaii and Trigonotis icumae. In the contrast, the phylogenetic relationships were resolved between Trigonotis peduncularis and Trigonotis coreana with low bootstrap $(\mathrm{BS}=57 \%)$ and high posterior probabilities $(\mathrm{PP}=0.87)$.

\section{Phylogenetic analysis of ITS data sets}

The maximum parsimony tree from the phylogenetic analysis of DNA sequences of the ITS of 20 accessions covering 5 species in Korean Trigonotis and L. zollingeri as an outgroup. The aligned data set of the ITS of nuclear ribosomal DNA is 656bp in length with sequences varying from 685bp (Trigonotis peduncularis) to 719bp (Trigonotis nakaii). In the phylogenetic analysis, the tree length of ITS regions is the highest (187 step) one among the other molecular markers, 72 characters were parsimony-uninformative and 498 were constant for ITS regions. The MP analysis, ITS showed the highest ratio of informative sites (13.11\%), while parsimony-informative of matK kept the smallest ratio $(0.14 \%)$ among 5 markers, with the consistency index $(\mathrm{CI}=$ $0.930)$ and retention index $(\mathrm{RI}=0.957)$ for the parsimony trees (Table 3). The broad phylogenetic relationships are similar between the NJ, MP and BI analyses and divided into two main clades: one clade with strongly bootstrap and high posterior probabilities $(\mathrm{BS}=100 \%$; $\mathrm{PP}=0.92)$ included Trigonotis radicans var. sericea, Trigonotis nakaii and Trigonotis icumae. In this clade, Trigonotis icumaae is a sister of the remained species. Within clade E, Trigonotis radicans var. sericea formed a polyphyletic. Although clade E has morderately bootstrap and high posterior probabilities values ( $\mathrm{BS}=84 \%$; $\mathrm{PP}=0.99$ ), the internal phylogenetic relationships were unresolved. The second lineage, with

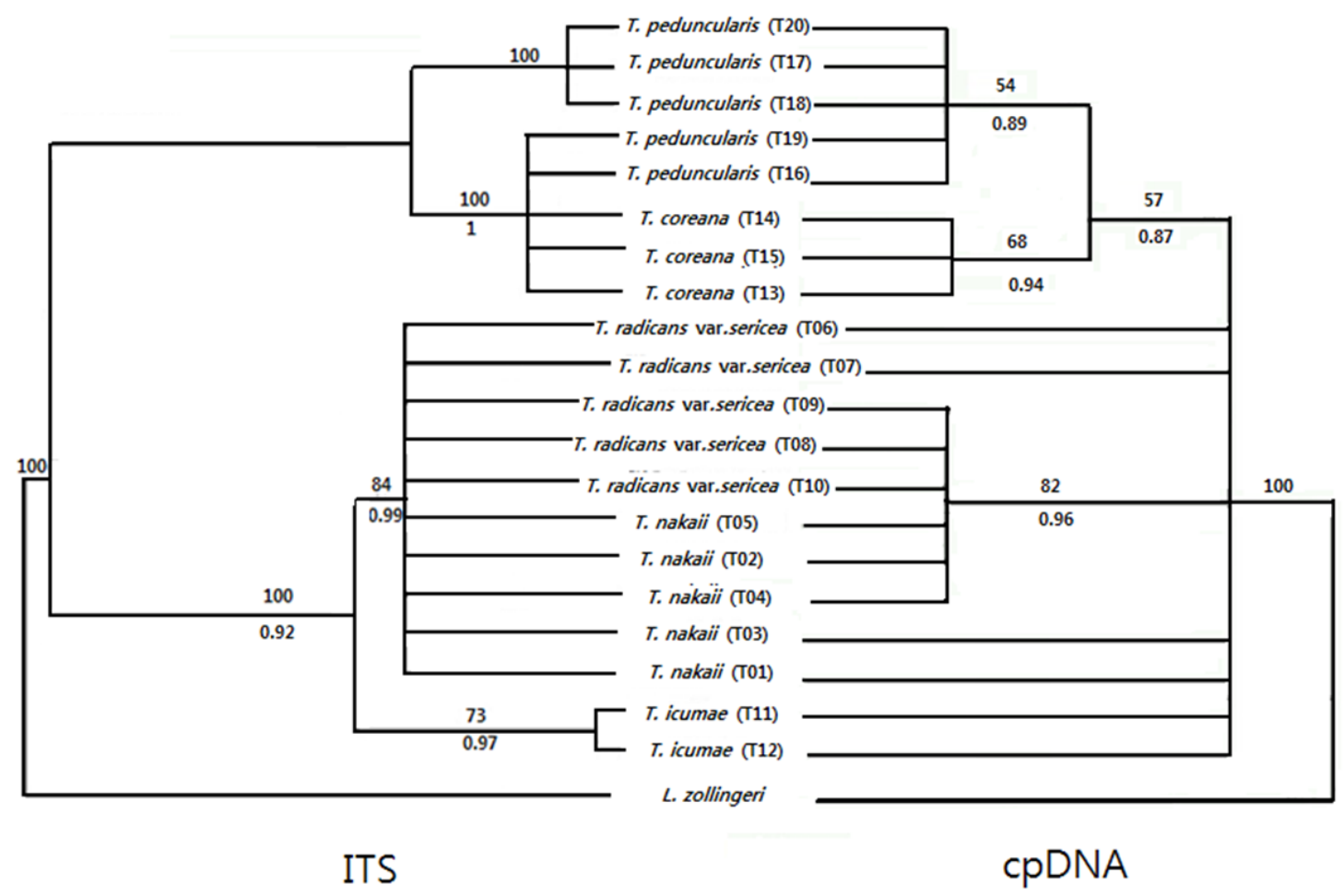

Fig. 1. Maximum parsimony analysis based on the analysis of nrDNA (left) and cpDNA (right) of Trigonotis species as a topological constraint and L.zolligeri as an outgroup. Bootstrap values are shown above branches and posterior probabilities values are shown under branches. 
moderately bootstrap and high posterior probabilities values $(\mathrm{BS}=85 \% ; \mathrm{PP}=0.95)$, Trigonotis peduncularis was polyphyletic. Within this clade, although two terminal clades were generated with strongly bootstrap and high posterior probabilities ( $\mathrm{BS} 100 ; \mathrm{PP}=1)$, the phylogenetic relationships were unresolved (Fig.1).

\section{Phylogenetic analyses based on combined cpDNA and ITS data}

The A total of 3526 characters were generated when combined cpDNA and nrDNA (ITS) sequences, 87 characters were parsimony-informative. The heuristic search produced 1623 steps with 1939 of constant and 1500 of parsimony uninformative. Maximum parsimony analysis resulted in 176 steps, with CI of 0.972; RI of 0.839 and RC of 0.935 (Table 3). The ILD test is used to examine of phylogenetic incongruence between nrDNA and cpDNAs, the incongruence between the nrDNA and chloroplast data sets was no significant incongruence $(p=0.01)$, thus they were analyzed in combination. By the way, the combined data tree topology had the same structure as the cpDNA phylogeny. The topology trees of Korean Trigonotis taxa from the NJ, MP and BI analysis provided the similar results. Phylogentic relationships are very similar between the total evidence trees obtained in the BI and MP analyses. Both MP and BI trees provided that phylogenetic relationships of Trigonotis taxa were divided into two main clades. Clade A was weakly bootstrap and low posterior probabilities values ( $\mathrm{BS}=60 \%$, $\mathrm{PP}=0.63$ ) and the relationship of Trigonotis icumea, receiving strongly bootstrap and high posterior probability, was resolved with the related species (Fig.2). In the clade D, Trigonotis peduncularis can be only distinghuished to Trigonotis coreana in BI analysis. In the MP tree, Trigonotis peduncularis was related to Trigonotis coreana.

\section{Discussion}

In the recent years, the comparative sequence analysis in systematic is an important tool for inferring phylogenetic relationships because of its fastening and convenience.

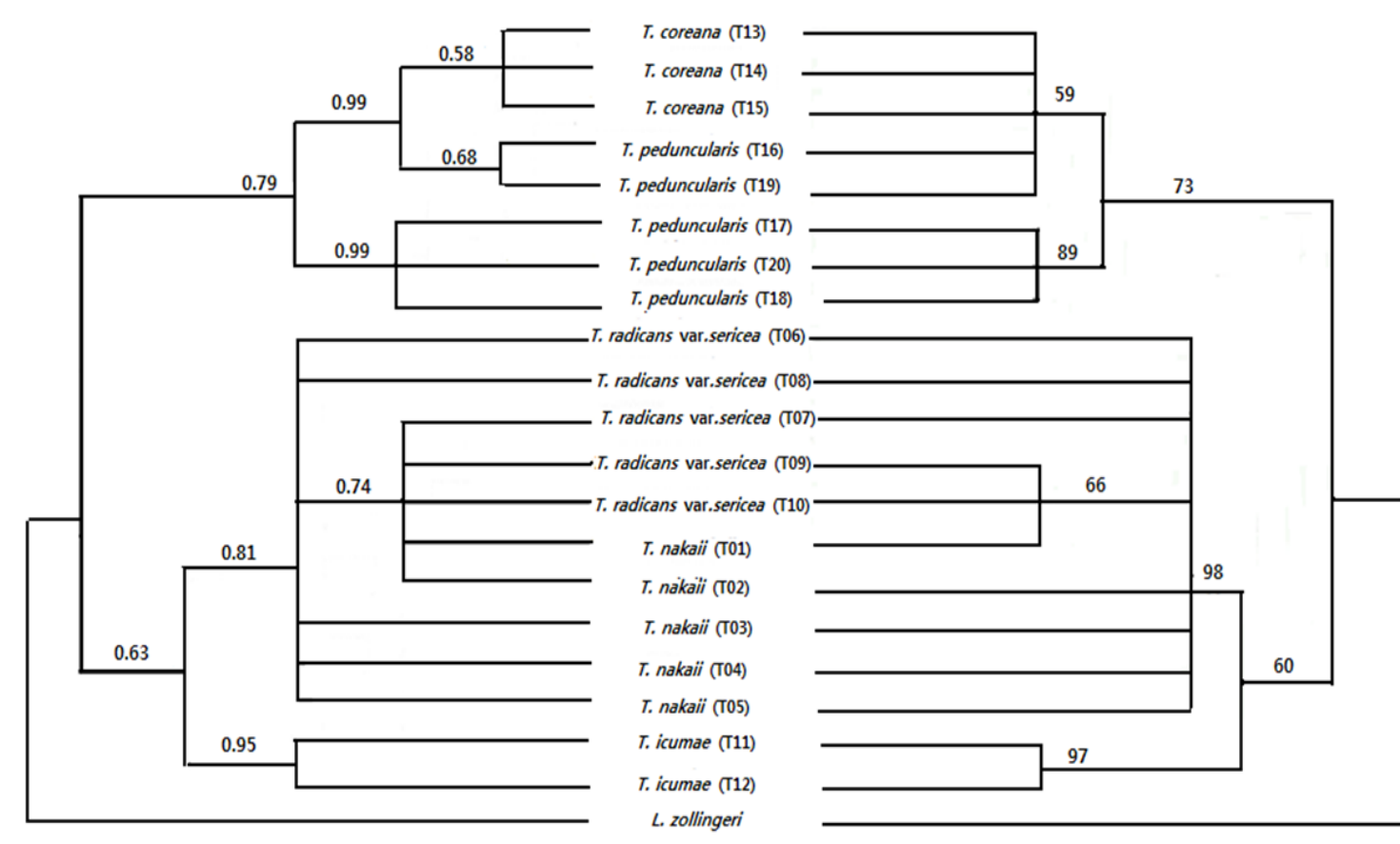

BI

Fig. 2. Phylogenetic tree of 21 Trigonotis individuals and L. zollingeri as an outgroup from MP analysis and BI analysis based on combined cpDNA and nrDNA. The posterior probabilities and Bootstrap values are shown above branches. 
Phylogenetic inference and elucidation of the evolutionary processes that generate biological diversity have been accomplished even at lower taxonomic levels using chloroplast genome and the ITSs of the nrDNA. In the present study, all the three cpDNA primers used successfully amplified the target regions in the Trigonotis species. Attempts to amplify the $r p o \mathrm{C} 1$ region were not successful in all the taxa. In this study, $n d h \mathrm{~F}$ provided the highest number of parsimonyinformative characters followed by $r b c \mathrm{~L}$ and mat $\mathrm{K}$ regions (Table.3). Of the cpDNA regions used in this study, the individual gene analyses have provided such a topology but low or $<50 \%$ support. (Savolainen et al., 2000a). The intergenic spacers were useful in the inference of phylogenetics at low taxonomic level in genera, the genus Korean Trigonotis is a particular example because the phylogenetic relationships between species are clearly unresolved.

Overall, the ITS data set provided a weaker signal than chloroplast data sets. The ITS topology was also less resolved the internal relationship between Trigonotis species, comparing to the chloroplast markers results (Fig.1). Tests clearly provided that the major relationships found by the plastid sequences were similar to those based on ITS. However, in general the internal relationships between species within section are unresolved. The findings are supported by Candolle's concept (1846) that Trigonotis var. sericea is synonym to Trigonotis nakaii. In addition, the results are shown that the phylogenetic relarionships between Trigonotis icumae and Trigonotis species are unresolved based on combined chloroplast sequences, comparing to ITS sequence (Fig.1). Furthermore, in the MP tree, Trigonotis coreana was within Trigonotis peduncularis group based on the ITS sequence but these species formed a separated group based on chloroplast sequences (Fig.1). Similarity, the phylogenetic relationship of Trigonotis nakaii and Trigonotis radicans var. sericeae were resolved in plastid tree, while this relationship cannot be found in ITS marker. In addition, Trigonotis taxa formed monophyletic group based on the combined plastid data sets, by contract, polyphyletic groups were reconstructed based on the ITS sequences (Fig.1). According to Small et al., (2004), nuclear DNA data sets in phylogenetic studies have traditionally been limited in classification between orthologous and paralogous sequences. However, at the infrageneric level, the ITS marker is a useful tool for resolving phylogenetic relationships at different taxonomic levels. The different combined data set is a contentious issue and numerous suggested methods for approaching the problems (Huelsenbeck et al., 1996), despite of the low incongruence or low bootstrap support for the incongruent nodes then data can be deemed to be combinable (e.g. Mason-Gamer and Kellogg 1996). The phylogenetic relationships of closely related taxa are inadequate resolution when using few cpDNA loci related to the low number of parsimony-informative characters (Rokas et al., 2003). Thus, the phylogenetic relationships of Korean Trigonotis taxa based on combined nuclear ribosomal DNA and chloroplast DNA markers were partly resolved. Both MP and BI trees showed the polyphyly of Trigonotis species and reconstructed major clades: the clade I included Trigonotis coreana and Trigonotis peduncularis and clade II comprised the remained taxa. Based on combined molecular markers, both MP and BI trees, shown Trigonotis coreana is related to Trigonotis peduncularis. These interesting results are conflict to the previous studies that Trigonotis radicans var. sericea and Trigonotis coreana are synonym species (De Candolle, 1846). The conclusions can be drawn from this study: firstly, the phylogenetic relationships of Trigonotis taxa were well unresolved based on separated chloroplast markers (not shown) because these regions do not contain enough information to resolved relationships between closely related genera. Both ITS and cpDNA trees, the DNA sequences resulted from the Triogonotis peduncularis is closest to Trigonotis coreana and Trigonotis radicans var. sericea is related to Trigonotis nakaii. Secondly, the combination of nuclear ribosomal DNA and chloroplast sequences helps to discriminate between Triogonotis species and provides more information for inference of phylogeny. Using additional rapidly evolving genomic regions is desirable to provide insight needed to improve our understanding of plant evolution. Ongoing studies further base on the non-coding chloroplast regions to find out the phylogenetic relationships within Trigonotis genus because the non-coding regions of chloroplast DNA are supplied to evolve more rapidly than coding regions. 


\section{Acknowledgement}

This research was supported by the research center for the policy suggestion of the Ministry of Educational Science.

\section{Literature Cited}

Azuma, T., T. Kajita, J. Yokoyama and H. Ohashi. 2000. Phylogenetic relationships of Salix (Salicaceae) based on rbcL sequence data. Amer. J. Bot. 87:67-75.

Baldwin, B.G. 1992. Phylogenetic utility of the internal transcribed spacers of nuclear ribosomal DNA in plants: an example from the Composite. Mol. Phylogenet. Evol. 1:3-16.

Bailey, C.D., T.G. Carr, S.A. Harris and C.E. Hughes. 2003. Characterization of angiosperm nrDNA polymorphism, paralogy, and psedogenes. Mol. Phylogenet. Evol. 29:435455.

Chase, M.W, R.S. Cowan, P.M. Hollingsworth, G. Petersen, O. Seberg, T. Jorgsensen, K.M. Cameron and M. Carine. 2007. A proposal for a standardized protocol to barcode all land plants. Taxon 56:295-299.

Cunningham, C.W. 1997. Can three incongruence tests predict when data should be combined?. Mol. Biol. Evol. 14(7): 733-740.

De Candolle, A.P. 1846. Trigonotis. In Prodromus systematis naturalis regni vegetabilis $\mathrm{X}$. Parisiis.

Doyle, J. and J. Doyle. 1987. A rapid DNA isolation procedure for small quantities of fresh leaf tissue. Phytochem. Bull. 19:11-15.

Feline, G.N. and J.A. Rosello. 2007. Better the devil you know? Guidelines for insightful utilization of nrDNA ITS in species- level evolutionary studies in plants. Mol. Phylogenet. Evol. 44:911-919.

Hilu, K.W, T. Borsch, K. Muller, D.E. Soltis, P.S. Soltis, V. Savolainen, M.W. Chase, M.P. Powell, L.A. Alice and R. Evans. 2003. Angiosperm phylogeny based on matK sequence information. Amer. J. Bot. 90:1758-1776.

Hipp, A.L., J.C. Hall and K.J. Sytsma. 2004. Congruence versus phylogenetic accuracy: revisiting the incingruence length difference test. Syst. Biol. 53(1):81-89.

Huelsenbeck, J.P., D.M. Hills and R. Jones. 1996. Parametric bootstrapping in molecular phylogenies: application and performance. Molecular zoology: advances, strategies, and protocols. 19-45. Wiley, New York, USA.
Jovanovic', V. and D. Cvetkovic'. 2010. Implications of $r b c \mathrm{~L}$ phylogeny for historical biogeography of genus Mercurialis L.: Estimating age and center of origin. Arch. Biol. Sci. 62:603-609.

Johnston, I.M. 1937. Studies in the Boraginaceae, XII. J. Arnold Arboretum 18:10-25.

Kress, W..J. and D.L. Erickson. 2007. A two-locus global DNA barcode for land plants: the coding $r b c \mathrm{~L}$ gene complements the non-coding trnH-psbA spacer region. PLoS One pp. e508.

Lahaye, R., M. Van der Bank, D. Bogarin, J. Warner, F. Pupulin, G. Gigot, O. Maurin, S. Duthoit, T.G. Barraclough and V. Savolainen. 2008. DNA barcoding the floras of biodiversity hotspots. PNAS. 105:2923-2928.

Les, D.H. 1994. Molecular systematics and taxonomy of lake cress (Neobeckia aquatica; Brassicaceae), an imperiled aquatic mustard. Aquatic Botany 49:149 - 165.

Lee, W.T. 1996. Standard illustrations of Korean Plants. Academy Press, Seoul, Korea. pp. 929-930 (in Korean).

Maddison, D.R. and W.P. Maddison. 2005. MacClade 4: Analysis of Phylogeny and Character Evolution. Version 4.08. Sinauer Associates, Sunderland, Massachusetts.

Mason-Gamer, R.J and E.A. Kellogg. 1996. Testing for phylogenetic conflict among molecular data sets in the tribe Triticeae (Gramineae). Syst. Biol. 45(4):524-545.

Maximowicz, C.J. 1872. Courtes diagnoses des nouvelles plantes du Japon et de la Mandijourie. Bulletin de I'Academic Imperiale des Sciences St. Petersbourg. 17:417-456.

Mayol, M. and J.A. Rosselo'. 2001. Why nuclear ribosomal DNA spacer (ITS) tell different stories in Quercus. Mol. Phylogenet. Evol. 19:167-176.

Muller, K.F, T. Borsch and K.W. Hilu. 2006. Phylogenetic utility of rapidly evolving DNA at high taxonomical levels: contrasting $m a t \mathrm{~K}$, $t r n T-F$, and $r b c \mathrm{~L}$ in basal angiosperms. Mol. Phylogenet. Evol. 41:99-117.

Nakai, T. 1917. Trigonotis Japono-Coreanae. Botanical Magazine Tokyo 31:215-218.

Newmaster, S.G., A.J. Fazekas and S. Ragupathy. 2006. DNA barcoding in the land plants: evaluation of $r b c \mathrm{~L}$ in a multigene tired approach. Can. J. Bot. 84:335-341.

Ohwi, J. 1953. Flora of Japan. Smithsonian Inst., Washington. USA.

Olmstead, R.G. and J.A. Sweere. 1994. Combining data in phylogenetic systematic: an empirical approach using three molecular data sets in the Solanaceae. Syst. Biol. 43:467-481. 
Olmstead, R.G., P.A. Reeves and A.C. Yen. 1998. Patterns of sequence evolution and implications for parsimony analysis of chloroplast DNA. Kluwer, Boston, Massachusetts, USA. pp. 164-187.

Popov, M.G. 1953. Boraginaceae in B.K. Shischkin Flora of the U.S.S.R.. Moskva and Leninggrad. 19:97- 691.

Ronquist, F., Huelsenbeck. 2003. MrBayes3: Bayesian phylogenetic inference under mixed models. Bioinformatics 19:1572-1574.

Rokas, A., B.L. Williams, N. King and S.B. Carroll. 2003. Genome-scale approaches to resolving incongruence in molecular phylogenies. Nature 425:798-840.

Sang, T., D.J. Crawford and T.F. Stuessy. 1997. Chloroplast DNA phylogeny, reticulate evolution and biogeography of Paeonia (Paeoniaceae). Amer. J. Bot. 84:1120-1136.

Savolainen, V., M.W. Chase, S.B. Hoot, C.M. Morton, D.E. Soltis, C. Bayer, M.F. Fay, A.Y. De Bruijn, S. Sullivan and Y.L. Qiu. 2000a. Phylogenetics of flowering plants based upon a combined analysis of plastid $a t p \mathrm{~B}$ and $r b c \mathrm{~L}$ gene sequences. Syst. Biol. 49:306-362.

Simmons, M.P. and H. Ochoterena. 2000. Gaps as characters in sequence based analyses. Syst. Biol. 49:369-381.

Small, R.L., R.C. Cronn and J.F. Wendel. 2004. Use of the nuclear genes for phylogeny reconstruction in plants. Aust. Syst. Bot. 17:145-170.

Soltis, D.E., E.V. Mavrodiev, J.J. Doyle, J. Rausher and P.S. Soltis. 2008. ITS and ETS sequence data and phylogeny reconstruction in allopolyploids and hybrid. Syst. Biol. 33:7-20.

Swofford, D.L 2002. PAUP*. Phylogenetic Analysis Using
Parsimony (and Other Methods), Version 4.0b10. Sinauer Associates, Sunderland, Massachusetts, USA.

Swofford, D.L. 2003. PAUP*: Phylogenetic analysis using parsimony Version 4.0b10 for 32-bit Microsoft Windows. Sinauer, Sunderland.

Sweeney, P.W. and R.A. Price. 2000. Polyphyly of the genus Dentaria (Brassicaceae): evidence from trnL intron and $n d h \mathrm{~F}$ sequence data. Syst. Bot. 25(3):468-478.

Xiang, Q.Y., D.E. Soltis, D.R. Morgan, and P.S. Soltis. 1993. Phylogenetic relationships of Cornus L. sensu lato and putative relatives inferred from $r b c \mathrm{~L}$ sequence data. Ann. Mo. Bot. Gard. 80:723-734.

Wang, C.J. 1982. Taxanomic and phytogeographic studies on Chinese species Trigonotis Steven. Acta. Bot. Yunnanica 4:31-45.

White, T.J., T. Bruns, S. Lee and J. Taylor. 1990. Amplification and direct sequencing of fungal ribosomal RNA genes for phylogenetics. A guide to methods and applications, UK edition. Academic Press, San Diego, USA. pp. 315-322.

Wolfe, K.H. 1991. Protein-coding genes in chloroplast DNA: compilation of nucleotide sequences, data base entries, and rates of molecular evolution. In Bogorad, L. and I.K. Vasil (eds.), Cell Culture and Somatic Cell Genetics of Plants. Academic Press, San Diego, USA. 7:467-482.

Zhu, G.L., H. Riedl, and R. Kametin. 1995. Trigonotis. In Wu, Z.Y. and P.H. Raven (eds.). Flora of China. Science Press, Beijing, China and Missouri Botanical Garden, St. Louis, USA. 16:361-373. 